\title{
On Translation of Euphemism in Business English from the Perspective of Bourdieu's Mode
}

\author{
Huijun Ren, Xing Wang, Yi Ling, Junhua Shi \\ School of Arts and Sciences, Shaanxi University of Science \& Technology, Xi'an, China \\ Email: 1150195644@qq.com
}

How to cite this paper: Ren, H. J., Wang, X., Ling, Y., \& Shi, J. H. (2022). On Translation of Euphemism in Business English from the Perspective of Bourdieu's Mode. Open Journal of Modern Linguistics, 12, 1-8.

https://doi.org/10.4236/ojml.2022.121001

Received: November 29, 2021

Accepted: January 4, 2022

Published: January 7, 2022

Copyright $\odot 2022$ by author(s) and Scientific Research Publishing Inc. This work is licensed under the Creative Commons Attribution International License (CC BY 4.0).

http://creativecommons.org/licenses/by/4.0/

\begin{abstract}
Strengthening international cooperation is inseparable from business negotiations and translation is necessary in the process of business negotiation. From the framework of Bourdieu's Mode on Sociological Translation Studies, the paper explores the application of this model in the translation of euphemism in business English with the leading concepts of fields and habits so that the impacts of the translator's habits and fields have been found on translation.
\end{abstract}

\section{Keywords}

Sociological Translation Studies, Bourdieu, Field, Habits, Euphemism, Business English

\section{Introduction}

In the context of today's global integration, timely and effective communication affects the effect of business negotiation, and the understanding and grasp of some potential or changes that might happen in international business negotiation communication has become a decisive factor in business negotiation. The so-called effective communication is through listening, speaking, reading, writing and other carriers, such as speeches, meetings, dialogues, discussions, letters and other ways to express their thoughts accurately and to promote better acceptance of the other party appropriately. Business negotiation is inseparable from effective communication, in such communication, people's behavior has the greatest impact. Most researchers had analyzed the translation of euphemism in business English from the social function, pragmatic functions, and politeness principle, but no one had done it from the perspective of Bourdieu's Mode. The 
study and translation from the angle of sociology is not a new concept. As early as 1972, Holmes had written in his book The Name and Nature of Translation Studies that sociological translation studies should be included as a part of translation studies (Holmes, 1988). It was not accepted by the public until the late 1990s that translation was regarded as a social behavior (Hermans, 1999). $\mathrm{Wu}$ (2008) analyzed the problems existing in the study of translation sociology. Wang (2011): The Name and Nature of Translation Sociology defines the research contents and methods of its discipline.

In international business negotiations, whether the translator can master the communication strategy is the key to successfully achieve the expected goal. Different translators may have different effects in the process, in addition to the translator's translation ability. In different social periods, social space in various fields, including translation field may show different characteristics. Translators may form different rituals in a specific field, and all sorts of capital may also be quite different. This paper, based on Bourdieu's social translation theory, examines the different translation of euphemisms in commercial texts by different translators under different habits, fields and capital so as to obtain a clearer understanding of the role translators play in the translation process.

\section{Sociological Translation Studies: Bourdieu's Mode}

\subsection{The Concept of Sociological Translation Studies}

The study and translation from the angle of sociology is not a new concept, as early as 1972, Holmes had written in his book The Name and Nature of Translation Studies that sociological translation studies should be included as a part of translation studies. But it didn't catch people's attention. Although the study of social translation in China is a bit later than that in the West, great achievements have been made. In particular, in the past decade, more and more scholars have begun to engage in sociological translation studies, and they have rapidly developed from simple translation and sporadic investigation into a more comprehensive and systematic exploration in China. For example, the theoretical construction of social translation studies, such as $\mathrm{Hu}$ (2006), he made a comprehensive and social interpretation of translation activities from 10 perspectives including social needs, social understanding and so on from the view of sociology; $\mathrm{Wu}$ (2008) explained the origin of translation sociology and analyzed three contemporary sociological theories: Bourdieu's social practice theory, Luhmann's social system theory and La tour's actor network theory. There is also a multidimensional perspective on social translation activities and social translation studies like $\mathrm{Fu}$ (2014), he reviewed the history of translation studies from the perspective of sociology, analyzed the name and reality of translation studies from this perspective, and took structure-functionalism as an example to discuss the determination of research boundaries and methods. Zhong and Feng (2014) analyzed the current situation of cultural translation studies and clarified the relationship between translation sociology and translation studies from the pers- 
pective of translation sociology in view of the imbalance of existing studies. With the social translation research model and research method of exploration, Shao (2012) focused on the general research methods of Sociology of Bourdieu, and introduced the core theory of the of translation in sociology-field theory in detail. He applied it in Chinese modern evaluation research to investigate the specific characteristics of modern Chinese translation field, and discussed the distinction of cultural and social hierarchy in the concept of applying in translation, and their theoretical and methodological impact. Wang (2016) focused on the issue of "name" and "nature". From the perspective of "name", he revealed and demonstrated the rationality of the existence of this discipline. It's effective in practical research and the scientific nature of its long-term development from the perspective of epistemology. At the same time, from the perspective of "nature", he defined the specific research object of this discipline from the perspective of ontology, and expounded its applicable research methods.

\subsection{Sociological Translation Studies: Bourdieu's Mode}

Bourdieu is one of the most famous contemporary French sociologists. Since the 1990s, his sociological theories have been increasingly cited by translation researchers. His core concepts mainly include practice, habitual, field and capital, which are the three central terms of the field theory in the field of translation.

1) Habits refer to the process in which people grow up, receive family education, study at school, work and communication, etc., and develop a set of their own "set system" through learning and summarizing, so that they tend to deal with problems according to their own habits and experiences. This is what Bourdieu called "habits", a characteristic of thoughts and behaviors that are both shaped by the environment and in turn affects it. Habits are a product of history and change, and evolve as society progresses. Unlike the rational actors of sociological theory of rational action and the individuals pursuing economic interests, Bourdieu's concept of habits emphasizes the thinking habits and behavioral tendencies cultivated by individuals in socialization, that is, the potential mechanism that enables them to make certain behaviors, which is a kind of "socialized subjectivity" (Bourdieu \& Wacquant, 1992). So, Bourdieu argues, participants are not necessarily rational, but always "reasonable".

In the above content, the author mentioned that the translator's habits are manifested in the field, that is, in the process of translation, the translator's behavior is actually a kind of internalized habits, which is constructed in the social construction, and these habits in turn construct other translation behaviors and choices of the translator. For example, in the translation of business negotiations, some translators tend to literally translate, that is, only translate the speaker's words, regardless of what the speaker really wants to deliver. Some translators tend to paraphrase and try to dig deeper meanings of the speaker. In this translation field, the habits of translator are restricted by the participants 
and the environment, and at the same time are crucial to the outcome of the negotiation.

2) The field is like a social space in Bourdieu's sociological theory, and the above-mentioned habits operate in this space. He believes that a field is a place where people compete for social benefits, such as cultural products, land, and power. There are various fields in society, and they are also related to each other. For example, scientific and technological researchers form a scientific field, and the business people form a commercial field. People with advanced education and rich theoretical knowledge belong to the field of science, and those with rich business experience belong to the field of business, which is the independent rule of each field. Scientific development requires economic sponsorship, and businessman's profit requires technology to support, which is the interaction between the various fields. The field is a structural system divided according to the functions of modern society.

3) Capital is a product in the field. There are four types of capital: economic capital, social capital, cultural capital and symbolic capital. Capital is closely related to the status of participants in the field. Due to the limited space, we cannot discuss capital and translation in this article.

\section{The Role of Euphemism in Business English}

The definition of euphemism in the Collins English-Chinese Dictionary of Foreign Education is: Euphemism is a polite word or expression that people use to talk about something unpleasant or embarrassing, such as death or sex. The word is derived from the Greek euphemism, which means "good words" and "speak in a good way". Euphemism is to regulate and ease the relationship between people. In the process of communication in business activities, applying euphemisms can effectively avoid embarrassment, and create an equal, friendly, and negotiated business environment, thereby creating a good atmosphere and achieving the expected results. Here, the author summarizes the role of euphemism in business activities.

\subsection{Build a Relatively Relaxing Atmosphere}

Business activities always make people tense and stressful, while using appropriate euphemism will be a lubricant to effectively ease the tension in business activities.

Example 1:

ST: In connection with the contract terms, we can agree to the first three points.

$\mathrm{TT}$ : 就合同条款而言，我们可以同意前三点。

The implication here is that we cannot agree with the remaining terms. This is a negative strategy. The speaker ignores the negative part and only selects the terms they agree with rather than rejecting them abruptly. This euphemism strategy is highly skillful and can be better accepted by the other party. 


\subsection{The Establishment of Long-Term Cooperative Relationship}

Obtaining economic benefits is the fundamental purpose of negotiations between both parties and even multiple parties. However, how to maximize their own profits requires certain skills. The function of euphemism is to create a good atmosphere in the negotiation process so that the negotiators can be prepared for unforeseen circumstances during negotiation between the two sides. Polite and tactful speech will make one side feel the respect and sincerity of the other side, avoiding unpleasant language conflict, which is more conducive to the long-term establishment of the cooperative relationship between the two sides.

\section{The Application of Bourdieu's Mode in Business English Euphemism Translation}

\subsection{Translator's Subjectivity under the Habits Theory}

In the process of translating, the translator's habits largely affect the process and result of translation. The translator's habits are formed from the translator's extensive translation practice, while the specific habits are formed from cultural fusion and collision. The translator's habits are manifested in the translator's translation strategy, translation style and other behaviors in the translation field. Some are not catering to ideological or political norms, but such translator's habits or we can say "collective unconsciousness" constructs a specific field to a certain extent, and at the same time, this established specific field, and which in turn affects the translator's behavior in the translation field.

Here are some examples of professional translation and nonprofessional translation, discussing the embodiment of the translator's subjectivity in the translation process under the influence of habits.

Example 2:

ST: 你回复的有点晚。

TT 1: Your reply is a little bit late.

TT 2: Your reply is late.

The use of "a little bit" in the first sentence makes the tone more polite, thus achieving the effect of not only letting the other party understand their fault, but also allowing the other party to accept it well. The tone of the second sentence is full of blame, which will affect the cooperation atmosphere and cooperative relationship between the two parties. It can be seen from the above two sentences that the former is more focused on context through professional training in translation, that is, in the case of intense business negotiations or correspondence, in addition to striving for benefits for oneself as much as possible, it also needs to be formed. A good atmosphere for business cooperation seeks the development of long-term cooperation. The latter lacks of professional training, and does not form corresponding business translation habit, but only pays attention to word-to-word translation, rather than the combination with context, which appears a hard translation. This is the habit of the translator in transla- 
tion. Here's another example.

Example 3:

ST: 我公司无法漠视贵方经常延期付款的事实。

TT 1: We can hardly overlook the fact that your payments have been delayed so frequently.

TT 2: We cannot overlook the fact that your payments have been delayed so frequently.

There are only slight differences between the two translations. In the process of receiving translation training, the former translator also considered the current context, and skillfully reduced negative words to express one's own views euphemistically, which not only expressed one's own views, but also avoided the embarrassment of the other party. The latter, as an ordinary translator, although the grammar and selection of words are indisputable, the use of strongly negative words such as "cannot" will make the other party feel unpleasant and may even affect the subsequent business cooperation.

\subsection{Translator Suitability under the Field Theory}

The "field" of translation is a controversial concept in translation studies. The so-called "field" is similar to the "magnetic field" in physics. It is not an actual object. It is a concept created to facilitate people to better understand the relationship in modern society. Translation activities have a certain network of relationships. The "field" is just a relatively opposed relational system relative to a specific relational network. The surrounding field and the right field penetrate each other, which can be understood as an inclusive relationship. At present, under the momentum of rapid economic development in our country, the "Belt and Road Initiative" has formed a unique commercial field. The "Belt and Road" runs through the Eurasian continent, encompassing more than 40 countries and more than 100 cities, involving nearly 3 billion people, which is considered to be "the longest economic corridor with the greatest development potential in the world". The progress of society is inseparable from economic progress. Therefore, the field of power has fully penetrated the field of translation. This influence is mainly manifested in the selection, review and distribution of translations by patrons (such as national institutions and publishers). The economic development of different regions cannot do without business negotiation, or we can say communication, so translation activities are also indispensable.

Business English negotiation under the background of the "Belt and Road" is different from business English negotiation in the general sense. In the traditional sense, business English negotiation involves all parties doing their best to fight for their own interests. It is a "game" process. The business negotiation under the background of the "Belt and Road" is to create a win-win situation to promote long-term cooperation, which is a new type of development method. In this process, the counter party of the negotiation is our potential partner rather than an opponent. Therefore, in such a business field, we need to use unique translation skills to strive for benefits. 
Example 4:

ST: I am afraid we can't go along with that suggestion at all.

TT: 我们不能同意这些提议。

There is another translation method for the above example: "We can't go along with that suggestion at all". In comparison, the former uses "I am afraid of..." to make the sentence more euphemistic and friendly. It is like a lubricant or buffer in a specific business field, so that the words will not appear too blunt and abrupt. However, the latter does not leave room for the other party in business negotiations, which makes it difficult for the other party to accept, and finally not conducive to the success of the negotiation.

In conclusion, the author provides several suggestions for translators: First, all translators' translations should follow a goal, that is, whether it is conducive to creating a business environment of equality, friendship and common consultation on the premise of ensuring the correct output of information, so as to establish a long-term cooperative relationship between the two parties; Secondly, negative words should be used skillfully and the strong negative words should be avoided using.

\section{Conclusion}

Translation activities exist because people from different languages and different cultures need to communicate. Interpersonal communication has social attributes, so it is reasonable and necessary to explore the phenomenon of translation from a sociological perspective. This article takes the Bourdieu Mode of the famous French sociologist of translation sociology as the research perspective, and combines the concepts of field and habits, and explores the influence of translator's "habits" and "field" in the process of translation activities, thus making the translation convey different effects. In business negotiations, in order to maximize their own interests, certain strategies are often adopted in the translation process, especially in the context of the "Belt and Road" negotiation, which requires smooth communication and even a good long-term cooperative relationship. Therefore, it is necessary to pay attention to the translator's translation of euphemisms in business English, especially at the level of "habits" and "field".

\section{Project Funding}

"Translation and Research of Traditional Chinese Medicine Classics Based on Translating Big Data”, a Major Research Project of Theoretical and Practical Issues in Philosophy and Social Sciences of Shaanxi Province, 2021 (Project No. 2021HZ0800).

\section{Conflicts of Interest}

The authors declare no conflicts of interest regarding the publication of this paper. 


\section{References}

Bourdieu, P., \& Wacquant, L. (1992). An Invitation of Reflexive Sociology. University of Chicago Press.

Fu, J. M. (2014). Sociological Approach to Translation: Problems and Future. Journal of Shanghai University (Social Sciences), No. 6, 101-111.

Hermans, T. (1999). Translation in Systems. Descriptive and System-Oriented Approaches Explained (p. 142). St Jerome Publishing.

Holmes, J. S. (1988). Translated! Papers on Literary Translation and Translation Studies. Rodopi. https://doi.org/10.1163/9789004486669

Hu, M. (2006). Translation Studies: From a Sociological Perspective. Foreign Languages and Their Teaching, No. 9, 48-51+55.

Shao, L. (2012). Modern Chinese Translation History Reinterpreted from a Bourdieuian Perspective Exemplified with the Cases of Yan Fu and Lin Shu. FLC, No. 1, 77-83.

Wang, H. T. (2011). Socio-Translation Studies: The Name and Nature of a Discipline under Construction. Chinese Translators Journal, 32, 14-18+93.

Wang, H. T. (2016). Ten Years of Socio-Translation Studies in China (2006-2016): Retrospect and Prospect. Shanghai Journal of Translators, No. 5, 49-55.

Wu, G. H. (2008). The Status Quo and the Limitations of the Sociology of Translation Studies. Journal of Foreign Languages, No. 1, 75-82.

Zhong, W. H., \& Feng, M. (2014). The Construction of Cultural Translation Research System from a Sociological Perspective. Foreign Languages Research, No. 3, 57-62. 